\title{
PRODUCTIVITY OF OAT (Avena sativa L.)-BERSEEM (Trifolium alexandrinum L.) FORAGE MIXTURE IN IRRIGATED PLAIN OF PAKISTAN
}

\author{
Muhammad Shoaib ${ }^{1, *}$ Muhammad Naeem Khan', Naveed Akhtar', Muhammad Ayub², \\ Muhammad Saeed Ashraf ${ }^{1}$, Abdul Ghaffar ${ }^{3}$, Sana Ullah ${ }^{1}$ \\ ${ }^{1}$ Ayub Agricultural Research Institute, AARI, Faisalabad, Pakistan; ${ }^{2}$ Department of Agronomy, University of \\ Agriculture, Faisalabad, Pakistan; ${ }^{3}$ Department of Agronomy, MNS-University of Agriculture, Multan \\ *Corresponding author's email: sho1578@ hotmail.com
}

\begin{abstract}
To assess the productivity of oat-berseem mixture in irrigated Indus plain of Pakistan, oat at four seeding rates $(100,75,50$, and 25\%) was intercropped with berseem. The mixed seeded crop was harvested at late stem elongation (LSE), early booting (EB) and early heading (EH) stage of oat. First cut mixture herbage dry matter (DM) yield was lower than oat monoculture. Berseem substantially recovered from suppression by oat prior to first cut. After two cuts, mixtures herbage DM and crude protein $(\mathrm{CP})$ yields were higher when first cut was taken at EH stage. On an average, first cut $\mathrm{CP}$ concentrations in mixtures were $11.25 \mathrm{~g} \mathrm{~kg}^{-1} \mathrm{DM}$ which was significantly higher as compared to oat monoculture. After two cuts, mixture with $25 \%$ oat ratio produced $6 \%$ higher $\mathrm{CP}$ yield than sole berseem. Fiber concentrations in mixtures were lower than sole oat in first cut while higher than sole berseem in re-growth cut. Thus mixing of oat seeding ratio as low as $25 \%$ combined with harvesting at EH cutting stage was proved to be more productive in terms of forage yield and quality.
\end{abstract}

Key Words: clover suppression, crude protein, cutting time, dry matter, Neutral detergent fiber

\section{INTRODUCTION}

In rural dairy production system of Pakistan, green forage crops provide only $10-15 \%$ of the total ruminant feed resources while major portion of remainder comes from grazing of pastures $(50-60 \%)$, wheat straw $(25 \%)$ and concentrates $(<5 \%)$ (Younas, 2013). In spite of favorable environment for forage production throughout the year, average green forage yield is very low. Intercropping is a lowtech tool employed for agricultural sustainability and intensification of cropping systems in which at least two crops are grown on same land and time scale to exploit morphological, physiological and ontogenetic differences of crops that complement each other in resource limited conditions.

Berseem has shown great promise to provide quality forage throughout Pakistan especially in irrigated Indus plain where it provides green forage from November to May through 5-6 cuttings, depending upon environmental conditions and agronomic management practices. However, berseem usually fails to cope the challenge of forage shortage during the period from November to December (one of the acute forage shortage period) owing to its slow growth rate in early growth phase (Ross et al., 2005a). The situation where summer forages like maize, millets and sorghum have just finished their growth and winter forages are still dormant, farmers take first cut of berseem even after 30 days from sowing resulting in lower forage yields. To compensate lower herbage DM yield of berseem during first cut, generally mono-cut cereals used as forage are mixed with berseem which have least inhibitory effect on subsequent re-growths of berseem.

Oat is a fast growing crop that gives high herbage DM yield and if harvested at stem elongation stage, its re-growth is favored by the prevailing temperature in Punjab during the months of December and January (daily average temperature $10-13{ }^{\circ} \mathrm{C}$ ) (Shoaib et al., 2013). It can provide handful quantity of green forage in 60-70 days period from sowing which is of great significance owing to its potential to provide forage during the months of December and January where annual clovers like berseem is greatly damaged by frost. Therefore, oat provides an economically and biologically viable option to be sown in mixture with berseem to enhance first cut herbage DM yield of berseem.

Productivity of binary mixture of cereal-legume for forage is greatly altered by choice of species and relative seed proportion. In cereal-berseem mixture cereal species and cereal densities largely determine the final composition and quality of mixture (Ross et al., 2005a). Small grain cereals in mixture with clovers greatly influence the growth of clover as cereals are more competitive than clover and can adversely affect the clover yield (Holland and Brummer, 1999). Oat in mixture with berseem substantially decreased berseem growth and yield prior to first cut (Ross et al., 2004; Holland and Brummer, 1999; Caballero et al., 1995) due to slower growth rate of berseem relative to oat. Ross et al. (2005a) recorded higher growth rate for oat (26-28 $\mathrm{g}$ herbage $\mathrm{DM} \mathrm{m}^{-2}$ $\left.\mathrm{d}^{-1}\right)$ than berseem (15-16 $\left.\mathrm{g} \mathrm{DM} \mathrm{m}^{-2} \mathrm{~d}^{-1}\right)$ after 35 days of growth 
in mixture which affects the dynamics of interaction among the mixture components.

In intercropping systems, temporal complementarity in intercrops is more probable to give higher yield advantage compared to spatial complementarity (Willey, 1979). Harvesting time is an important temporal management factor in determining forage yield and quality of mixtures (Rinne and Nykanen, 2000). According to Marshall et al. (1992) cereal crop should be harvested earlier to favor the establishment of perennial forage crop. Furthermore, herbage biomass yield and quality is often negatively related. However, stage of balance between herbage DM yield and quality varies among species. The oat-berseem mixture is hardly been studied in irrigated Indus plains where both crops have vigorous growth, hence information on optimum seeding ratio of both component crops in the mixture and suitable time of cutting is scarce. Therefore, the objective of this study was to optimize oat seeding rate for oat-berseem mixture in Indus plains along with suitable time of cutting for mixture that not only provide reasonable forage in terms of quality and quantity at first harvest but also ensures adequate berseem re-growth later in the season.

\section{MATERIALS AND METHODS}

Experiment was conducted at Agronomic Research Area, University of Agriculture, Faisalabad ( $\left(31^{\circ} 26^{\prime} \mathrm{N}\right.$ and $73^{\circ} 05^{\prime} \mathrm{E}$, altitude 184 meters) during winter season of the two consecutive years 2010-11 and 2011-12. Mean monthly temperature and precipitation at the experimental site is given in Table 1. Field was flat and well drained with sandy clay loam soil texture. Other chemical characteristics of experimental soil are depicted in Table 1.

The previous crop in 2010-11 was pearl millet which was harvested 40 days before sowing of experiment. In 2011-12 land was fallow for 6 months after the harvest of wheat in May, 2011. Preparation of the experiment during both years started with the application of $10 \mathrm{~cm}$ pre-sowing irrigation. In 2010-11, leftovers of the previous pearl millet crop were mixed in soil by rotavator when field reached the proper moisture level. Finally, during both years, seed bed was prepared by cultivating the field thrice by tractor mounted cultivator up to the depth of $30 \mathrm{~cm}$ followed by planking.

Experimental treatments consist of four seeding combinations and three cutting times of the mixture which were laid out in randomized complete block design (factorial arrangement) with three replications. Four seeding ratios (SR) were $\mathrm{SR}_{1}$, $\mathrm{SR}_{2}, \mathrm{SR}_{3}$ and $\mathrm{SR}_{4}$ which were designed by combining 100 , 75,50 and $25 \%$ of recommended seed rate of oat $\left(75 \mathrm{~kg} \mathrm{ha}^{-1}\right)$ with $100 \%$ seed rate of berseem $\left(20 \mathrm{~kg} \mathrm{ha}^{-1}\right)$, respectively. Three cutting time were later stem elongation (LSE), early booting (EB) and early heading (EH) stage that corresponds to Zadoks scale of 35-36, 45 and 52. Sole crops of oat and berseem were also maintained to evaluate the performance of mixtures and treated as control. Oat was sown with single row hand drill in $30 \mathrm{~cm}$ apart rows in $3 \mathrm{~m} \times 6 \mathrm{~m}$ plot. Just after oat sowing plots were irrigated and berseem seed was broadcasted in standing water (common practice in Punjab). To meet the mineral requirement of component crops in mixtures, a uniform dose of N-P as urea and di-ammonium phosphate, respectively, were applied at the rate of $60-80 \mathrm{~kg}$ $\mathrm{ha}^{-1}$. Phosphorus was applied at the time of sowing while nitrogen in two splits i.e., half at sowing and half before first irrigation. Resultantly each experimental unit consists of 10 rows of oat with berseem broadcasted over the plot. Rainfall was too low to sustain crop growth (Table 1) so three irrigations each of $7.5 \mathrm{~cm}$ depth were applied at 35, 65 and 100 days after sowing when the field reached to field capacity. At each cutting time, oat and berseem plants from whole plot were harvested separately and weighed for green forage yield. Then, separate representative samples of oat and berseem from each plot was chopped to a theoretical length of $1 \mathrm{~cm}$ and a subsample of $500 \mathrm{~g}$ was dried in oven at $60{ }^{\circ} \mathrm{C}$ till constant weight to calculate the herbage DM yield. Dried

Table 1. Pre-sowing soil characteristics, mean monthly precipitation $(\mathrm{mm})$ and temperature $\left({ }^{\circ} \mathrm{C}\right)$ at experimental site over seven months in the years 2010-11 and 2011-12.

\begin{tabular}{lcccc}
\hline & \multicolumn{2}{c}{ Rainfall $(\mathbf{m m})$} & \multicolumn{2}{c}{ Temperature $\left({ }^{\circ} \mathbf{C}\right)$} \\
\hline Month & $\mathbf{2 0 1 0 - 1 1}$ & $\mathbf{2 0 1 1 - 1 2}$ & $\mathbf{2 0 1 0 - 1 1}$ & $\mathbf{2 0 1 1 - 1 2}$ \\
\hline October & 0.0 & 0.4 & 26.3 & 24.7 \\
November & 0.0 & 0.0 & 18.8 & 20.5 \\
December & 1.0 & 0.0 & 13.3 & 12.5 \\
January & 0.0 & 3.8 & 10.1 & 10.2 \\
February & 20.6 & 8.0 & 14.4 & 11.5 \\
March & 6.8 & 1.5 & 19.6 & 18.8 \\
April & 20.9 & 10.5 & 24.8 & 25.3 \\
\hline
\end{tabular}

April

Pre-sowing soil physical and biochemical characteristics

\begin{tabular}{|c|c|c|c|c|c|c|c|c|c|c|c|}
\hline \multicolumn{6}{|c|}{ 2010-11 } & \multicolumn{6}{|c|}{ 2011-12 } \\
\hline pH & $E C(d S / m)$ & $\operatorname{OM}(\%)$ & $\mathbf{N}(\%)$ & $\mathbf{P}(\mathbf{p p m})$ & K (ppm) & pH & EC (dS/m) & OM(\%) & N\% & $\mathbf{P}(\mathrm{ppm})$ & K (ppm) \\
\hline 7.8 & 1.53 & 0.73 & 0.039 & 6.6 & 131 & 8.1 & 1.58 & 0.77 & 0.042 & 7.2 & 119 \\
\hline
\end{tabular}


samples were ground to be powdered. These samples of forage were analyzed for nitrogen percentage, neutral detergent fiber (NDF) and acid detergent fiber (ADF) concentrations. Nitrogen \%, determined by Kjeldahl Flask method (AOAC, 1990) was multiplied with 6.25 to calculate crude protein concentrations. This $\mathrm{CP}$ concentration was used to calculate $\mathrm{CP}$ yield $\mathrm{ha}^{-1}$. Concentrations of NDF and ADF were determined as by Van Soest and Robertson (1980). Each quality parameter was determined separately on each fraction of mixture i.e. oat and berseem and were manipulated to estimate for the mixture using prescribed techniques.

Statistical analysis: All the statistical analyses were performed by SAS 9.1.3 (SAS Institute Inc., Cary, NC, USA, 2002-03). Data of both years was pooled after conducting tests regarding heterogeneity of variances. Significance of treatments was tested by analysis of variance technique through PROC GLM (SAS Institute, 2002). Year and replications were considered as random effects while cutting time and seed rate were taken as fixed effects. Significance of cutting time and seed rate was determined by using year $x$ cutting and year $\times$ seed rate as error term, respectively.
Significant year $\times$ cutting/seed rate effect was ignored as interactive effect was small compared to average main effect and ranking of treatments was same across the years (Gomez and Gomez, 1984). Least significant difference (LSD) test $(\mathrm{P}=0.05)$ was carried out to assess the effect of cutting time on response variables. However, response variables to seeding ratios were compared with appropriate control term by applying Dunnett's two-tailed 't test' under equal variance assumption. Correlation between berseem percentage and $\mathrm{CP} \%$, first cut $\mathrm{CP}$ yield, NDF and ADF concentration of mixed forage was detected by Pearson Correlation Coefficient through PROC CORR (SAS Institute, 2002) while graphs were drawn through PROC GPLOT (SAS Institute, 2002).

\section{RESULTS}

Dry Matter Production: Effect of cutting time, seeding ratios and interaction of cutting time $\times$ seeding ratio was significant on herbage DM yields of mixture in first and re-growth cut (Table 2).

$\mathrm{DM}$ production increased $(\mathrm{P}<0.05)$ from $\mathrm{LSE}$ stage to $\mathrm{EH}$

Table 2. Sources of variation for first cut and total herbage $D M$ and $C P$ yields $\left(\mathrm{kg} \mathrm{ha}^{-1}\right)$, first cut $\mathrm{CP}$ concentrations ( $\left.\mathrm{g} \mathrm{kg}^{-1} \mathrm{DM}\right)$, first cut and re-growth NDF and ADF concentrations $\left(\mathrm{g} \mathrm{kg}^{-1} \mathrm{DM}\right)$ for oat-berseem mixture.

\begin{tabular}{|c|c|c|c|c|c|c|c|c|c|c|c|}
\hline & $\begin{array}{c}\text { First cut } \\
\text { herbage } \\
\text { DM yield }\end{array}$ & $\begin{array}{c}\text { Berseem } \\
\%\end{array}$ & $\begin{array}{c}\text { Re-growth } \\
\text { herbage DM } \\
\text { yield }\end{array}$ & $\begin{array}{c}\text { Total } \\
\text { herbage } \\
\text { DM yield }\end{array}$ & $\begin{array}{c}\text { First cut CP } \\
\text { concentrations }\end{array}$ & $\begin{array}{l}\text { First cut } \\
\text { herbage } \\
\text { CP yield }\end{array}$ & $\begin{array}{c}\text { Total } \\
\text { herbage } \\
\text { CP yield }\end{array}$ & $\begin{array}{l}\text { First cut } \\
\text { NDF } \\
\text { conc. }\end{array}$ & $\begin{array}{l}\text { Re-growth } \\
\text { NDF conc. }\end{array}$ & $\begin{array}{l}\text { First cut } \\
\text { ADF conc. }\end{array}$ & $\begin{array}{l}\text { Re-growth } \\
\text { ADF conc. }\end{array}$ \\
\hline Cutting & $* *$ & * & ns & * & $*$ & $*$ & $*$ & * & $*$ & $*$ & * \\
\hline $\mathbf{Y} \times \mathbf{C}$ & ns & ns & ns & ns & ns & ns & ns & ns & ns & ns & ns \\
\hline SR & $* *$ & $* *$ & $*$ & $* *$ & * & $* *$ & $* *$ & $* *$ & $* *$ & $* *$ & $*$ \\
\hline $\mathbf{Y} \times \mathbf{S R}$ & ns & ns & ns & ns & ns & ns & ns & ns & ns & ns & ns \\
\hline $\mathbf{C} \times \mathbf{S R}$ & $* *$ & $*$ & $* *$ & $*$ & ns & $*$ & $* *$ & ns & $* *$ & $* *$ & $* *$ \\
\hline $\mathbf{Y} \times \mathbf{C} \times \mathbf{S R}$ & ns & ns & ns & ns & ns & ns & ns & ns & ns & ns & ns \\
\hline
\end{tabular}

$\prod$ data was pooled over two winter seasons of the years 2010-11 and 2011-12. $\mathrm{Y}=\mathrm{year}, \mathrm{C}=\mathrm{cutting}, \mathrm{SR}=\mathrm{seed}$ rate

Table 3. Mean first cut DM yield $\left(\mathrm{kg} \mathrm{ha}^{-1}\right)$, berseem \% in first cut, re-growth cut and total (first + re-growth cut) dry matter yields $\left(\mathrm{kg} \mathrm{ha}^{-1}\right)$ of oat-berseem mixture at different seeding rates of oat and cutting stages at first cut

\begin{tabular}{|c|c|c|c|c|}
\hline & $\begin{array}{c}\text { First cut herbage DM } \\
\text { yield }\end{array}$ & Berseem \% & $\begin{array}{l}\text { Re-growth herbage } \\
\text { DM yield }\end{array}$ & $\begin{array}{c}\text { Total herbage DM } \\
\text { yield }\end{array}$ \\
\hline \multicolumn{5}{|c|}{ Seeding ratios } \\
\hline $\mathrm{SR}_{1}$ & $7493(-627 *)$ & $7.42(-92.57 *)$ & $5676(-2890 *)$ & $13169(3615 *)$ \\
\hline $\mathrm{SR}_{2}$ & $7439(-681 *)$ & $9.55\left(-90.45^{*}\right)$ & $6617(-1948 *)$ & $14057(4502 *)$ \\
\hline $\mathrm{SR}_{3}$ & $7301(-819 *)$ & $12.96(-87.03 *)$ & $7257(-1309 *)$ & $14558(5003 *)$ \\
\hline $\mathrm{SR}_{4}$ & $6563(-1557 *)$ & $20.04\left(-79.95^{*}\right)$ & $8348(-218 *)$ & $14911(5357 *)$ \\
\hline Sole berseem & $2501(-5620 *)$ & 100.00 (Control) & 8566 (Control) & $11066(1512 *)$ \\
\hline Sole oat & (8120) Control & & & 9554 (Control) \\
\hline $\mathrm{LSD}_{0.05}$ & 261.9 & 81.11 & 200.7 & 303.30 \\
\hline \multicolumn{5}{|c|}{ Values with ' $*$ ' in parenthesis is the significant difference from control $(p<0.05)$} \\
\hline \multicolumn{5}{|l|}{ Cutting stage } \\
\hline LSE & $3000 \mathrm{c}$ & $16.91 \mathrm{a}$ & $7554 \mathrm{a}$ & $10011 \mathrm{c}$ \\
\hline EB & $6225 \mathrm{~b}$ & $11.29 \mathrm{~b}$ & $6705 \mathrm{~b}$ & $11812 \mathrm{~b}$ \\
\hline $\mathrm{EH}$ & 10485 a & $9.29 \mathrm{c}$ & 7619 a & $16835 \mathrm{a}$ \\
\hline $\mathrm{LSD}_{0.05}$ & 143.6 & 0.62 & 123.9 & 166.3 \\
\hline
\end{tabular}

Values within column having distinct letter are significantly different $(\mathrm{p}<0.05)$

$\mathrm{SR}_{1}=$ oat $100 \%$ :berseem $100 \%, \mathrm{SR}_{2}=$ oat $100 \%$ :berseem $75 \%, \mathrm{SR}_{3}=$ oat $100 \%$ :berseem $50 \%, \mathrm{SR}_{4}=$ oat $100 \%:$ berseem $100 \%$, $\mathrm{LSE}=$ Late stem elongation, $\mathrm{EB}=$ Early booting, $\mathrm{EH}=$ Early Heading 
stage (Table 3). From LSE to EB stage DM production increased by $107 \%$ while from $\mathrm{EB}$ to $\mathrm{EH}$ increase was $68 \%$ indicating higher DM production during LSE to EB stage. Herbage DM yield of the first cut increased with each increment of oat seeding ratio in mixture. A noticeable increase of $1177 \mathrm{~kg} \mathrm{ha}^{-1}$ herbage DM yield was observed when oat seeding ratio was increased from $25 \%$ to $50 \%$ at $\mathrm{EH}$ cutting stage (Fig. 2a).

Berseem herbage DM yield at all seeding ratios were substantially less $(\mathrm{P}<0.05)$ in mixture compared to sole berseem. Berseem contents accounted for only $17 \%$ of the first cut herbage DM yield at LSE stage and this share faced a further substantial decrease to $9 \%$ at $\mathrm{EH}$ cutting stage. Averaged over seeding ratios, berseem share in first cut herbage DM yield in mixtures was $12.49 \%$ and even with the presence of $25 \%$ oat seeding rate, berseem constituted only $20.04 \%$ of first cut herbage DM yield. Comparing to berseem monoculture, average berseem first cut herbage DM yield in mixtures was $87 \%$ less $(\mathrm{P}<0.05)$. Highest berseem $\%$ $(27.42 \%)$ was recorded at $25 \%$ oat ratio when mixture was cut at LSE stage (Fig 1).

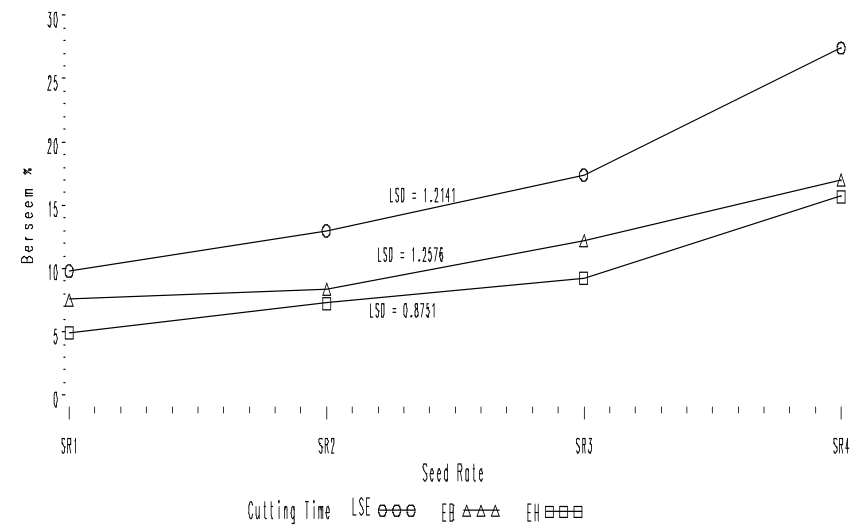

Figure 1. Berseem \% in oat-berseem mixture harvested at three cutting stages of oat under four seeding ratio of oat. LSD0.05 values differentiate means at same cutting time.

Substantial oat re-growth was witnessed only when first cut was taken at LSE stage. Re-growth herbage DM yield from all mixtures were lower $(\mathrm{P}<0.05)$ than re-growth from berseem monoculture. Re-growth herbage DM yield from mixtures was negatively associated with oat seeding ratio as mixture with $100 \%$ oat seeding ratio produced $32 \%$ less herbage DM yield than the mixture with $25 \%$ oat seeding ratio.

Cutting the mixture at early (LSE) or later (EH) stage produced similar re-growth herbage DM yield (Table 3). A handful oat re-growth from mixtures that were cut at LSE stage contributed to higher re-growth herbage DM yield. While higher re-growth herbage DM yield when first cut was at EH stage may be connected to relatively higher temperature that prevailed during corresponding re-growth period i.e. March and April (Table 1). A prominent increase of $2464 \mathrm{~kg}$ $\mathrm{ha}^{-1}$ in re-growth herbage DM yield was recorded when oat seeding ratio in sowing mixture was reduced from $50 \%$ to $25 \%$ (Fig. 2b).

(a)

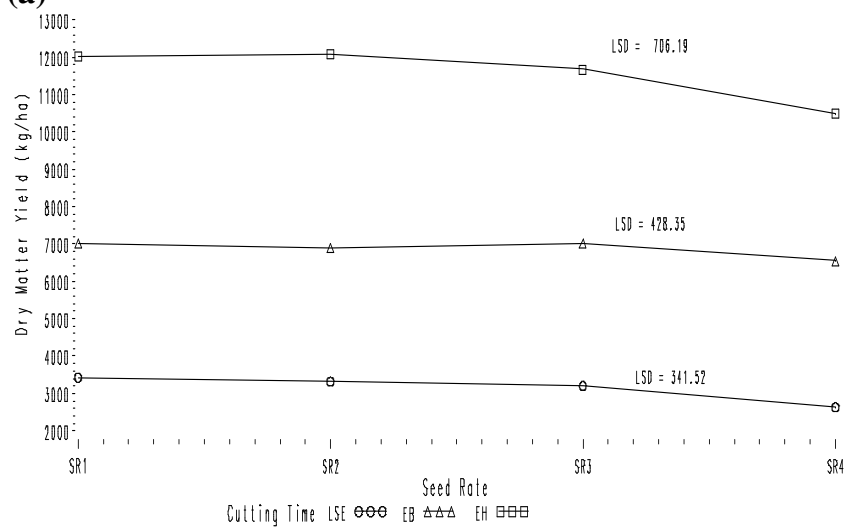

(b)

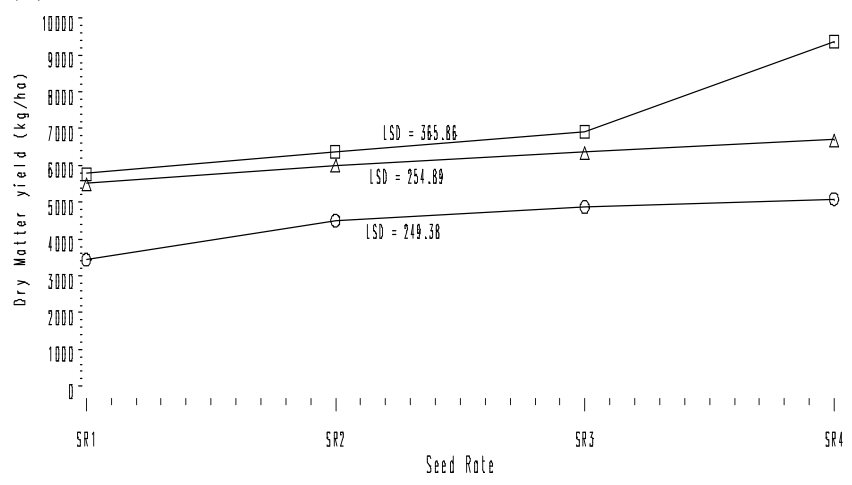
Cutting Tine LSE $000 \quad$ EB $\triangle \Delta B H$

(c)

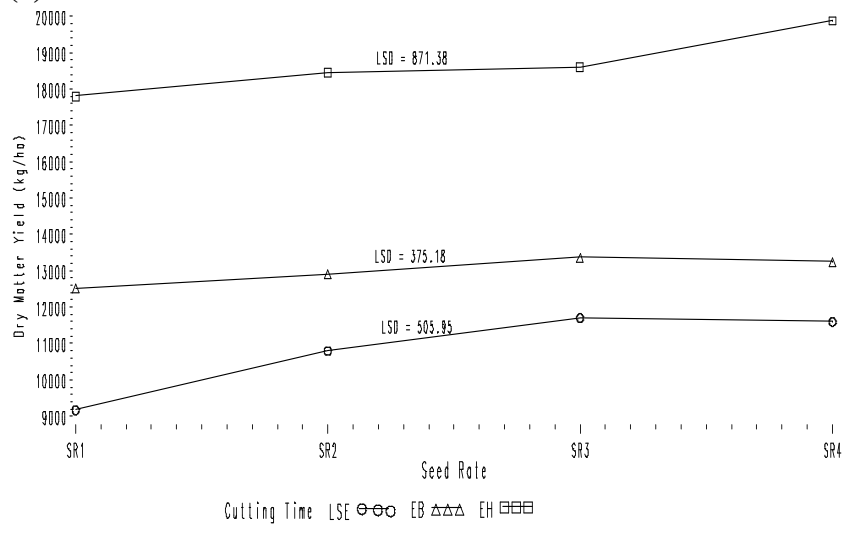

Figure 2. First cut (a), re-growth cut (b) and total herbage DM yields (c) of oat-berseem mixture harvested at three growth stages of oat under four seeding ratios of oat. LSD0.05 values differentiate means at same cutting time. 
The herbage DM yield of first two cut increased $(\mathrm{P}<0.05)$ as time of first cut was delayed from LSE to EH. Mixtures cut at EH stage yielded $68 \%$ and $50 \%$ higher total herbage DM yield than mixtures cut at LSE and EB stage, respectively. After two cuts, total herbage DM yield of all mixtures was higher $(\mathrm{P}<0.05)$ than sole oat. Highest total herbage DM yield (14911 kg ha $\mathrm{kg}^{-1}$ ) was recorded for the treatment with $25 \%$ oat ratio and it decreased as the seeding ratio of oat in sowing mixture was increased. In two cut system, sole oat produced the lowest herbage DM yield and even sole berseem produced $16 \%$ higher herbage DM yield than sole oat. Cutting the mixture at LSE and EB stage, total herbage DM yield increased with decreased oat proportion up to $50 \%$, however further reduction of oat ratio slightly decreased the total herbage DM yield. However, cutting the mixture at EH stage, herbage DM yield showed remarkable increase of $1287 \mathrm{~kg} \mathrm{ha}^{-}$ ${ }^{1}$ with a reduction of oat ratio from $50 \%$ to $25 \%$ after two cuts (Fig. 2c). Hence, oat-berseem mixture proved to be superior in DM production than sole cropping of oat or berseem to ensure sustainable forage supply throughout the winter season.

CP and Forage Quality: Effect of cutting time and seeding rate was significant $(\mathrm{P}<0.05)$ on first cut $\mathrm{CP}$ concentrations, first cut and total (first cut + re-growth cut) $\mathrm{CP}$ yield, first cut $\mathrm{ADF}$ and second cut NDF and ADF concentrations. Interactive effect of cutting time and seed rate was also significant for all quality attributes except for first cut CP concentrations (Table 2).

Crude protein concentrations recorded in all mixtures were higher $(\mathrm{P}<0.05)$ as compared to oat monoculture (Table 4). The CP concentrations were the highest $\left(212.26 \mathrm{~g} \mathrm{~kg}^{-1} \mathrm{DM}\right)$ in berseem monoculture whereas the lowest $\left(120.43 \mathrm{~g} \mathrm{~kg}^{-1}\right.$ $\mathrm{DM})$ in oat monoculture. However, this outcome had little impact on CP concentrations of the oat-berseem mixture. On an average $\mathrm{CP}$ in mixtures was $11.25 \mathrm{~g} \mathrm{~kg}^{-1} \mathrm{DM}$ higher compared to oat monoculture. A tendency of increasing $\mathrm{CP}$ concentrations with decreasing oat seeding ratio in mixture was recorded during first cut. Mixtures showed an improvement of $3.56 \mathrm{~g} \mathrm{~kg}^{-1} \mathrm{DM}$ in $\mathrm{CP}$ concentrations when oat seeding ratio in mixture was lowered from $100 \%$ to $75 \%$ however improvement was $7.85 \mathrm{~g} \mathrm{~kg}^{-1} \mathrm{DM}$ when seeding ratio was lowered from $50 \%$ to $25 \%$.

$\mathrm{CP}$ concentrations of the mixtures decreased with delaying the time of first cut. CP concentrations dropped by $45.54 \mathrm{~g}$ $\mathrm{kg}^{-1} \mathrm{DM}$ from LSE to EH stage. However, decrease in $\mathrm{CP}$ concentrations was relatively sharper from EB to EH stage amounting $25.36 \mathrm{~g} \mathrm{~kg}^{-1} \mathrm{DM}$ compared to $20.18 \mathrm{~g} \mathrm{~kg}^{-1} \mathrm{DM}$ from LSE to EB stage.

First cut and total $\mathrm{CP}$ yield increased $(\mathrm{P}<0.05)$ with successive cutting time from LSE to $\mathrm{EH}$. Berseem percentage in mixture was too low to make any impression in $\mathrm{CP}$ yield. A moderately negative $(\mathrm{r}=-0.53, \mathrm{P}<0.0001)$ correlation was detected between berseem $\%$ and $\mathrm{CP}$ yield at first cut which could be explained by the corresponding lower herbage DM yield where berseem $\%$ in mixture was high (Table 3 ). While a strong positive correlation $(\mathrm{r}=0.75, \mathrm{P}<0.0001)$ was found between berseem $\%$ and $\mathrm{CP}$ concentrations. In first cut, $\mathrm{CP}$ yield increased by $81.37 \%$ from LSE to EB while a further $35.41 \%$ increase was recorded up to $\mathrm{EH}$ stage this corresponds to $107 \%$ and $68 \%$ increase in herbage DM yield, respectively.

Oat monoculture produced highest $(\mathrm{P}<0.05)$ first cut herbage $\mathrm{CP}$ yield which is attributed to higher DM production (Table 5), though its difference from mixtures having $75 \%$ and $50 \%$ oat seeding ratio was not significant. Berseem monoculture produced $43 \%$ lower $\mathrm{CP}$ yield than oat monoculture. Herbage CP yield at two early cutting stages (LSE and EB) increased slightly by decreasing oat seeding ratio up to $50 \%$, however, a further decrease in oat seeding ratio reduced the $\mathrm{CP}$ yield (Fig. 3a). At $\mathrm{EH}$ stage $\mathrm{CP}$ yield showed a decreasing trend as oat ratio was lowered from $75 \%$ to $25 \%$.

Total herbage $\mathrm{CP}$ yield (first + re-growth cut) showed an increase of $18 \%(\mathrm{P}<0.05)$ from LSE to EB stage. However, the highest total herbage CP yield ( $\left.2585 \mathrm{~kg} \mathrm{ha}^{-1}\right)$ was recorded when first cut was taken at EH stage of oat. After two cuts, herbage $\mathrm{CP}$ yield of all mixtures surpassed oat monoculture. Among mixtures, total herbage $\mathrm{CP}$ yield increased with

Table 4. First cut crude protein concentrations $\left(\mathrm{g} \mathrm{kg}^{-1} \mathrm{DM}\right)$ of the oat-berseem mixture and monocultures at different seeding rates of oat and cutting stages of the mixture at first cut.

\begin{tabular}{|c|c|c|c|c|c|c|}
\hline Seeding Ratios & & & & & & \\
\hline & $\mathbf{S R}_{1}$ & $\mathbf{S R}_{2}$ & $\mathbf{S R}_{3}$ & $\mathbf{S R}_{4}$ & Berseem & Oat \\
\hline CP concentrations & $\begin{array}{l}124.46 \\
\left(4.04^{*}\right)\end{array}$ & $\begin{array}{c}128.02 \\
(7.60 *)\end{array}$ & $\begin{array}{c}133.09 \\
(12.67 *)\end{array}$ & $\begin{array}{c}140.94 \\
(20.52 *)\end{array}$ & $\begin{array}{c}212.26 \\
(91.84 *)\end{array}$ & $\begin{array}{l}120.425 \\
\text { (control) }\end{array}$ \\
\hline
\end{tabular}
Cutting time

\begin{tabular}{|c|c|c|c|}
\hline & LSE & EB & EB \\
\hline CP concentrations & $165.11 \mathrm{a}$ & $144.92 \mathrm{~b}$ & $119.56 \mathrm{c}$ \\
\hline
\end{tabular}


Shoaib, Ayub, Akhtar, Khan, Ashraf, Ghaffar \& Ullah

Table 5. First cut and total (first + re-growth cut) herbage CP yields $\left(\mathrm{kg} \mathrm{ha}^{-1}\right)$ and NDF and ADF concentrations (g $\mathrm{kg}^{-1} \mathrm{DM}$ ) of oat-berseem mixture at different seeding rates of oat and cutting stages at first cut.

\begin{tabular}{|c|c|c|c|c|c|c|}
\hline & \multirow{2}{*}{$\begin{array}{c}\text { First cut herbage } \\
\text { CP Yield } \\
\left(\mathrm{kg} \mathrm{ha}^{-1}\right)\end{array}$} & \multirow{2}{*}{$\begin{array}{l}\text { Total herbage } \\
\text { CP Yield } \\
\left(\mathrm{kg} \mathrm{ha}^{-1}\right)\end{array}$} & \multicolumn{2}{|c|}{ NDF $\left(\mathrm{g} \mathrm{kg}^{-1} \mathrm{DM}\right)$} & \multicolumn{2}{|c|}{ ADF $\left(\mathrm{g} \mathrm{kg}^{-1} \mathrm{DM}\right)$} \\
\hline & & & First cut & $\begin{array}{l}\text { Re-growth } \\
\text { cut }\end{array}$ & First cut & $\begin{array}{l}\text { Re-growth } \\
\text { cut }\end{array}$ \\
\hline & Seeding ratios & & & & & \\
\hline $\mathrm{SR}_{1}$ & $867(-41 *)$ & $2088(1031 *)$ & $464.8(-7.3 *)$ & $326.0(35.3 *)$ & $297.5(-2.5 \mathrm{~ns})$ & $259.3(20.8 *)$ \\
\hline $\mathrm{SR}_{2}$ & 881 (-27ns) & $2301(1244 *)$ & $459.3(-12.9 *)$ & $323.6(32.9 *)$ & $294.5(-5.5 *)$ & $258.0\left(19.6^{*}\right)$ \\
\hline $\mathrm{SR}_{3}$ & 899 (-9 ns) & $2451(1394 *)$ & $449.4\left(-22.8^{*}\right)$ & $324.0(33.3 *)$ & $291.0(-8.9 *)$ & $257.6(19.1 *)$ \\
\hline $\mathrm{SR}_{4}$ & $850\left(-58^{*}\right)$ & 2647 (1590*) & $437.1\left(-35.1^{*}\right)$ & $322.3\left(31.6^{*}\right)$ & $286.4\left(-13.6^{*}\right)$ & $256.0\left(176^{*}\right)$ \\
\hline Berseem & $515\left(-393^{*}\right)$ & $2498(1441 *)$ & $329.8(-142.5 *)$ & 290.7(Control) & $255.2\left(-44.8^{*}\right)$ & 238.5(Control) \\
\hline Sole oat & 908 (Control) & 1057(Control) & 472.2 (Control) & - & 300 (Control) & - \\
\hline \multirow[t]{3}{*}{$\mathrm{LSD}_{0.05}$} & 0.326 & 0.513 & 6.95 & 2.24 & 3.32 & 1.39 \\
\hline & Values with ' $^{*}$ ' in 1 & nthesis is the $\mathrm{s}$ & ificant differenc & rom control $(\mathrm{p}$ & $.05)$ & \\
\hline & Cutting stage & & & & & \\
\hline LSE & $4.7 \mathrm{c}$ & $17.8 \mathrm{c}$ & $360.1 \mathrm{c}$ & $295.1 \mathrm{c}$ & $224.0 \mathrm{c}$ & $229.5 \mathrm{c}$ \\
\hline EB & $8.5 \mathrm{~b}$ & $21.5 \mathrm{~b}$ & $448.0 \mathrm{~b}$ & $314.3 \mathrm{~b}$ & $298.0 \mathrm{~b}$ & $242.8 \mathrm{~b}$ \\
\hline $\mathrm{EH}$ & $11.5 \mathrm{a}$ & $25.9 \mathrm{a}$ & $498.2 \mathrm{a}$ & $342.5 \mathrm{a}$ & $340.3 \mathrm{a}$ & $289.3 \mathrm{a}$ \\
\hline $\mathrm{LSD}_{0.05}$ & 1.79 & 0.28 & 3.78 & 1.37 & 1.82 & 8.50 \\
\hline
\end{tabular}

Values within column having distinct letter are significantly different $(\mathrm{p}<0.05)$

$\mathrm{SR}_{1}=$ oat $100 \%$ :berseem $100 \%, \mathrm{SR}_{2}=$ oat $100 \%$ :berseem $75 \%, \mathrm{SR}_{3}=$ oat $100 \%$ :berseem $50 \%, \mathrm{SR}_{4}=$ oat $100 \%:$ berseem $100 \%$, $\mathrm{LSE}=$ Late stem elongation, $\mathrm{EB}=$ Early booting, $\mathrm{EH}=$ Early Heading

decreased oat seeding ratio in sowing mixtures. Mixture with $25 \%$ oat seeding ratio produced $150 \%$ higher $(\mathrm{P}<0.05) \mathrm{CP}$ yield than oat monoculture. After two cuts, sole berseem also produced $136 \%$ higher CP than sole oat.

Concentrations of NDF and ADF in first and re-growth cut were positively related with time of first cut (Table 5). Oat monoculture produced highest $(\mathrm{P}<0.05) \mathrm{NDF}$ and $\mathrm{ADF}$ concentrations than mixtures and berseem monoculture at each cutting stage. Mixture with $100 \%$ oat seeding ratio produced slightly lower NDF concentrations than sole oat and difference was 9.85, 7.82 and $4.79 \mathrm{~g} \mathrm{~kg}^{-1} \mathrm{DM}$ at LSE, EH and EB stage, respectively (Fig. 3b). However, a substantial reduction $(\mathrm{P}<0.05)$ in NDF concentration of $46.4,30.9$ and $28.1 \mathrm{~g} \mathrm{~kg}^{-1} \mathrm{DM}$ was recorded for mixture with $25 \%$ oat seeding ratio from oat alone at LSE, EB and EH stage, respectively.

First cut mixture NDF concentrations were higher than regrowth cut at all growth stages studied (Table 5). Moreover, concentrations of NDF in berseem re-growth from mixtures was higher $(\mathrm{P}<0.05)$ than re-growth from sole berseem. Among mixtures, NDF concentrations decreased with decreased oat seeding rate (Table 5). Mixture with $25 \%$ oat seeding rates produced $35.1 \mathrm{~g} \mathrm{~kg}^{-1} \mathrm{DM}$ lower NDF concentrations compared to sole oat. Sole berseem recorded $142.5 \mathrm{~g} \mathrm{~kg}^{-1} \mathrm{DM}$ lower NDF concentrations than sole oat. The effect of $\mathrm{CT} \times \mathrm{SR}$ was not significant on NDF concentrations in first cut (Table 2).

In first cut, ADF concentrations increased by $74 \mathrm{~g} \mathrm{~kg}^{-1} \mathrm{DM}$ $(\mathrm{P}<0.05)$ from LSE to $\mathrm{EB}$ as compared to $42.3 \mathrm{~g} \mathrm{~kg}^{-1} \mathrm{DM}$ $(\mathrm{P}<0.05)$ from $\mathrm{EB}$ to $\mathrm{EH}$ cutting stage. All mixtures produced lower $(\mathrm{P}<0.05)$ ADF concentrations than oat alone except the mixture with $100 \%$ oat seeding ratio (Table 5). A moderately strong negative correlation $(\mathrm{r}=-0.59, \quad \mathrm{P}<0.0001)$ was identified between berseem $\%$ and ADF concentrations in first cut. Similarly, sole berseem yielded $44.8 \mathrm{~g} \mathrm{~kg}^{-1} \mathrm{DM}$ lower $(\mathrm{P}<0.05)$ ADF than sole oat. In re-growth cut, ADF concentrations from mixtures were higher $(\mathrm{P}<0.05)$ than regrowth cut of berseem monoculture. Within the mixtures, regrowth cut ADF concentrations decreased with decreased proportion of oat in sowing mixture. The mixture with $25 \%$ oat seeding ratio produced $17.6 \mathrm{~g} \mathrm{~kg}^{-1} \mathrm{DM}$ higher $(\mathrm{P}<0.05)$ ADF which was the minimum difference from sole berseem than other mixtures. A significant $\mathrm{CT} \times \mathrm{SR}$ effect depicts variable effect of seed rate on $\mathrm{ADF}$ concentration at three cutting time (Fig. 3c).

(Fig. 3a, b, c)

\section{DISCUSSION}

Dry matter production: Stage of first cut and oat seeding ratio in oat-berseem mixture altered the productivity of the mixture. Herbage dry matter yield of the mixtures and monocultures during first cut increased as cutting was delayed. Increase in herbage DM yield was expected as DM yields of most species increase up to anthesis (Dear et al., 2005). Quantitative increase in herbage DM yield from LSE stage to EH stage is quite comparable to that reported by Ross et al. (2005a), who also found higher herbage DM yield increase form stem elongation to booting (104\%) than form booting to heading stage $(77 \%)$ over a range of oat densities 
in oat-berseem mixture. Herbage DM yield of the mixtures during first cut increased with each increment of oat seeding ratio in mixture. Tendency of increasing herbage DM yield with increasing oat seeding ratio suggest oat as herbage DM yield determining crop in the mixture. Similarly, Ross et al. (2004) found that oat, barley and triticale were the main contributor in first cut herbage DM yield in cereal-berseem mixture over a range of cereal seeding densities.

(a)

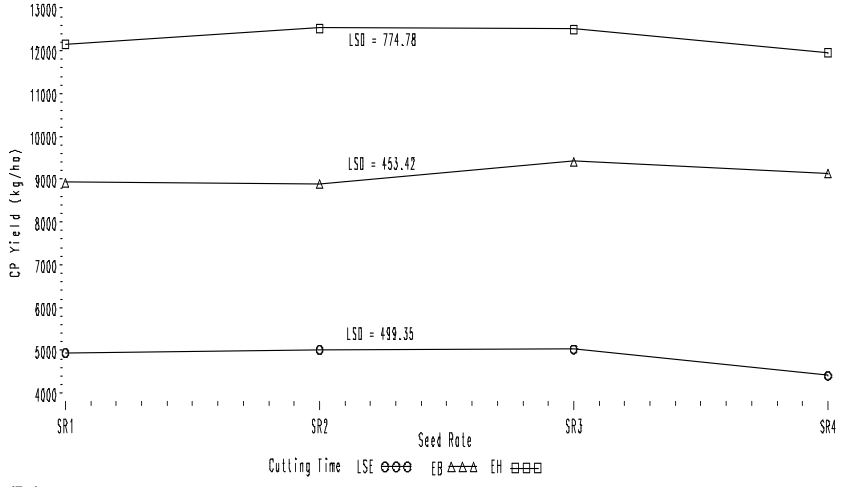

(b)

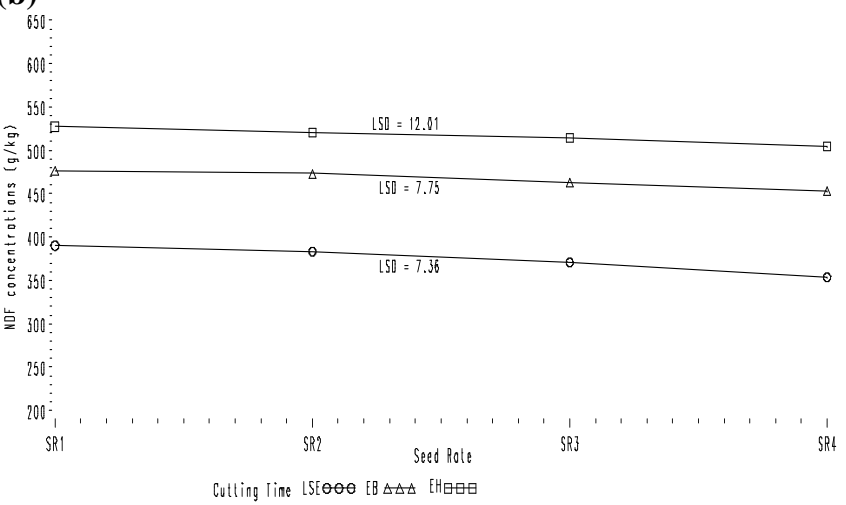

(c)

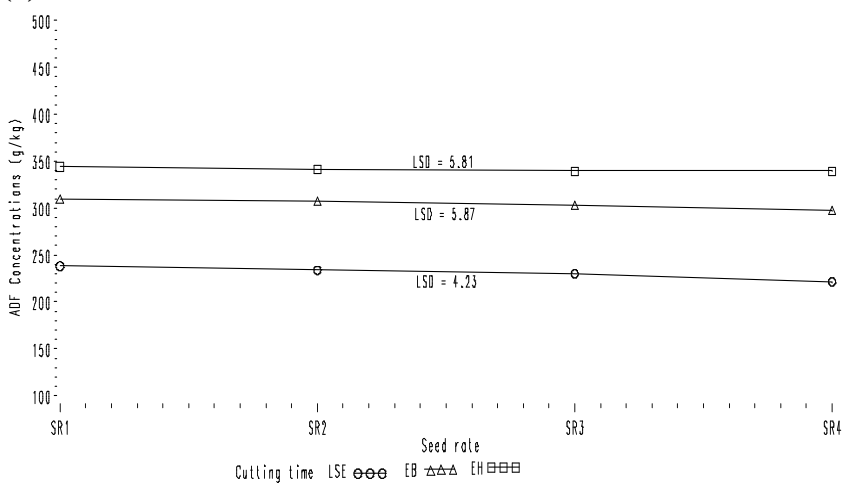

Figure 3. Crude protein yield (a), NDF (b) and acid detergent fiber (c) of oat-berseem mixture harvested at three growth stages of oat under four seeding ratios of oat. $\mathrm{LSD}_{0.05}$ values differentiate the means at same cutting time.
Oat greatly suppressed berseem in mixture and suppression intensified as time of their co-existence lengthened. Similarly, Frame (1987) also observed reduction in white clover proportion in clover-ryegrass mixture herbage DM produce with delayed harvesting. All the oat seeding ratios have profound effect on first cut DM yield of berseem. According to Ross et al. (2005b), in cereal-clover mixture for forage, sowing rate of cereal has some substantial consequences on proportion of cereal and clover herbage DM yields. Likewise, considerably lower berseem herbage DM yield percentage in mixture with oat during first cut has previously been reported by Ross et al. (2004) and Ross et al. (2003), who found it to be as lower as 6 and 4\%, respectively. Many characters of cereals like early plant establishment, faster and deeper root establishment, supplementary demands for nutrients (Fujita et al., 1992; Hauggaard-Neilsen et al., 2001, 2003) and plant height contribute to their competitiveness for light, inorganic N (Hauggaard-Nielsen et al., 2008), soil moisture and cause shading effect (Mauro et al., 2011; Kyriazopoulos et al., 2012) on berseem in mixture. Oat plants in mixtures greatly reduce the light intensity to berseem (Ross et al., 2005a) that might have affected the photosynthetic efficiency of berseem. Watson et al. (1984) observed that berseem herbage DM yield at $50 \%$ and $75 \%$ shade was $88 \%$ and $56 \%$ of the beseem yield under full sun, respectively. Increase in berseem share with decreased oat seeding ratio proposes that berseem took advantage of less competition and more photosynthetically active radiation (PAR) infiltration at reduced oat density (Armstrong et al., 2008). Similar to our study, Ross et al. (2005a) concluded that berseem \% in first cut herbage DM yield can be promoted by reducing of competition from cereal and early timing of first cut.

Oat was deprived of re-growth when first cut was delayed up to EB and EH stage that confirm the previous report by Smith (2007) who stated that oat cut at heading stage do not re-grow. Possibility of oat re-growth cut depends upon the stage of first cut (Gunsaulis et al., 2008) and height of cutting as cutting too low may remove the growing points. In this study, we harvested the mixture at approximately $5 \mathrm{~cm}$ height from ground that might have removed growing points resulting in negligible re-growth even when first cut was at early booting stage. Previously, Ross et al. (2003) have also reported negligible oat re-growth from oat-berseem mixture when first cut was taken 11 weeks after planting.

Berseem re-growth herbage DM yield from mixtures was lower than that from berseem monoculture owing to oat being the dominant component in mixtures prior to first cut. According to Ross et al. (2005a) lack of initial space for berseem to establish will reduce its re-growth ability and they further concluded that lessened residual leaf area of berseem in intercrop with oat affected its re-growth compared to berseem monoculture. While results are also in agreement with Ross et al. (2004), Ross et al. (2003) and Holland and Brummer (1999), who found negative correlation between 
first cut oat herbage DM yield and berseem re-growth DM yield. Lower mixture herbage DM yield at reduced oat seeding ratios during first cut was compensated by corresponding higher berseem re-growth herbage DM yield. One of the objectives of this study was to assess the possibility of enhancing the first cut herbage DM yields of berseem by sowing a mixture of berseem and oat which largely seems true at all seeding ratios of oat.

After two cut herbage, DM yield of mixtures at all seeding ratios exceeded oat monoculture. Similar results from timothy-red clover mixture have previously been reported by Rinne and Nykanen (2000). In mixtures, oat was the herbage DM yield determining factor in first cut. While vigorous regrowth of berseem provided sustained supply of forage later in the season. However, the decision about the time to harvest the oat-berseem mixture depends on the type of livestock to be fed and balance between forage requirement and availability at the farm.

$\boldsymbol{C P}$ and forage quality: Although berseem presence in mixture improved the first cut $\mathrm{CP}$ concentrations of mixtures at all seeding ratios but this improvement was not considerable (Table 4). This relatively small impression of berseem in spite of higher $\mathrm{CP}$ concentrations on mixture $\mathrm{CP}$ concentrations is attributed to very small share of berseem in first cut herbage DM yield (Table 3). Similarly, Stout et al. (1997) reported that berseem inclusion to barley-ryegrass mixture improved mixture $\mathrm{CP}$ concentrations of first cut. Relatively steep drop in mixture CP concentrations after EB stage witnessed in this study is well supported by the previous study of Khorasani et al. (1997), who also reported a sharp decrease in CP concentration after booting stage in small grain cereals and can be attributed to decreased leave to stem ratio (Rinne and Nykanen, 2000) and rapid conversion of photosynthates to structural components with time that decrease protein and soluble carbohydrates while increase structural cell wall contents (Ammar et al., 2004).

Crude protein yield depends on DM yield (Atis et al., 2012). Higher herbage $\mathrm{CP}$ yields at later cutting stage and increased oat seeding ratio can solely be explained by corresponding greater DM production. Likewise, Ross et al. (2005b) also observed increase in CP yield of oat-berseem mixture (First + re-growth cut) as first cut was delayed to heading stage. Herbage DM yield was the determining factor in first cut herbage CP yield that is why the relatively higher berseem share in mixture with $25 \%$ oat seeding ratio could not sustain the CP yield. Similar results have previously been reported by Vasilakoglou and Dhima (2008), when they intercropped berseem with barley.

Fiber concentrations of the animal feed (NDF and ADF) are a measure of feed digestibility and intake. ADF is an estimate of total cell wall contents comprising of cellulose and lignin while NDF is the total fiber contents including ADF and hemicellulose. Fibrous contents in plants increase with maturity of plant (Khorasani et al., 1997) and similar trend was found in our study. Decreased leaf: stem ratio and more stem DM accumulation with maturity could be responsible for this outcome. Temperature gradually increased from February to April (Table 1) which may be accounted for higher fiber concentrations in re-growth cut. Mela (2003) demonstrated that crude fiber $\%$ of grass and red clover in mixture is a function of accumulated temperature.

Mixtures produced significantly lower NDF and ADF concentrations during first cut compared to oat monoculture owing to berseem presence in mixture. Similar to our study, Ross et al. (2005a) and Ross et al. (2004) observed $30 \mathrm{~g} \mathrm{~kg}^{-1}$ DM and 25 to $45 \mathrm{~g} \mathrm{~kg}^{-1}$ DM decrease in NDF concentrations by berseem inclusion in mixture with small grain cereals. According to Kocer and Albayrak (2012) and Albayrak et al. (2011) cereals have higher cell wall contents than legumes at same maturity and environmental conditions.

First cut mixture NDF and ADF concentrations at each stage were higher corresponding re-growth cut which primarily is attributed to oat being major component of herbage DM yield in first cut and berseem in re-growth cut. Shading effect on berseem prior to first cut might have elongated berseem stem (Buxton and Mertens, 1995) and resulted in reduced leaf: stem ratio (Ross et al., 2005a) which could possibly be the reason of higher fiber concentrations in re-growth cut from intercropped berseem compared to re-growth from berseem monoculture.

Conclusions: In Indus plain, oat-berseem mixture is highly productive. However, higher oat seeding ratio in mixture significantly reduced the berseem growth prior to first cut that resultantly affected its re-growth. Though, berseem showed a great potential to recover from oat suppression faced during primary growth and yielded re-growth DM comparable to regrowth from sole berseem. Furthermore, inclusion of oat in mixture at $25 \%$ seeding rate gave reasonable DM yields with on average $20 \%$ berseem contents during primary growth and also ensured vigorous berseem re-growth. Vigorous growth of oat during primary growth combined with potential of berseem to recover in re-growth provides the farmers with chance to harvest mixture over relatively longer period of time.

\section{REFERENCES}

Albayrak, S., M. Turk, O. Yuksel and M. Yilmaz. 2011. Forage yield and the quality of perennial legume-grass mixtures under rainfed conditions. Not. Bot. Horti. Agrobo. 391:114-118.

Ammar, H., S. Lopez, J.S. Gonzalez and M.J. Ranilla. 2004. Chemical composition and in vitro digestibility of some Spanish browse plant species. J. Sci. Food Agric. 84:197204. 
AOAC. 1990. Association of Official Analytical Chemists. Official Methods of Analysis. $15^{\text {th }}$ Ed. Arlington, Virginia, USA.

Armstrong, K.L., K.A. Albrecht, J.G. Lauer and H.C. Riday. 2008. Intercropping corn with lablab bean, velvet bean, and scarlet runner bean for forage. Crop Sci. 41:371-379.

Atis, I., K. Kokten, R. Hatipoglu, S. Yilmaz, M. Atak and E. Can. 2012. Plant density and mixture ratio effects on the competition between common vetch and wheat. Aust. J. Crop Sci. 6:498-505.

Buxton, D.R. and D.R. Mertens. 1995. Quality-related characteristics of forages. P. 83-110. In: R.F. Barnes, D.A. Miller and C.J. Nelson (eds.), The Science of Grassland Agriculture. 5 ${ }^{\text {th }}$ Ed., Vol. II. Iowa State University Press, Iowa, USA.

Caballero, R., E.L. Goicoechea and P.J. Hernaiz. 1995. Forage yields and quality of common vetch and oat sown at varying seeding ratios and seeding rates of common vetch. Field Crops Res. 41:135-140.

Dear, B., A. Kaisar and J. Piltz. 2005. Yield and digestibility of legume and oat for forages. Primefact 52. Department of Primary Industries. New South Wales, Australia.

Frame, J. 1987. The effect of strategic fertilizer nitrogen and date of primary harvest on the productivity of a perennial ryegrass/white clover sword. Grass and Forage Sci. 42:33-42.

Fujita, K., K.G. Ofosu-Budu and S. Ogata. 1992. Biological nitrogen fixation in mixed legume cereal cropping systems. Plant Soil 141:155-175.

Gomez, K.A. and A.A. Gomez. 1984. Statistical Procedures for Agricultural Research. $2^{\text {nd }}$ Ed. John Wiley and Sons Publication Company, New York, USA.

Gunsaulis, J.L., W.K. Coblentz, R.K. Ogden, R.K. Bacon, K.P. Coffey, D. S. Hubbell, J.V. Skinner Jr., M.S. Akins, J.D. Caldwell, K.S. Lusby and S.A. Gunter. 2008. Fall growth potential of cereal grain forages in northern Arkansas. Agron. J. 100:1112-1123.

Hauggaard-Nielsen, H., P. Ambus and E.S. Jensen. 2001. Interspecific competition, $\mathrm{N}$ use and interference with weeds in pea-barley intercropping. Field Crop Res. 70:101-109.

Hauggaard-Nielsen, H., P. Ambus and E.S. Jensen. 2003. The comparison of nitrogen use and leaching in sole cropped versus intercropped pea and barley. Nutr. Cycl Agroecosyst. 65:289-300.

Hauggaard-Nielsen, H., B. Jørnsgaard, J. Kinane and E.S. Jensen. 2008. Grain legume-cereal intercropping: the practical application of diversity, competition and facilitation in arable and organic cropping systems. Renew. Agr. Food Syst. 23:3-12.

Holland, J.B. and E.C. Brummer. 1999. Cultivar effects on oat-berseem clover intercrops. Agron. J. 91:321-329.

Khorasani, G.R., P.E. Jedel, J.H. Helm and J.J. Kennelly. 1997. Influence of stage of maturity on yield components and chemical composition of cereal grain silages. Can. J. Anim. Sci. 77: 259-267.

Kocer, A. and S. Albayrak. 2012. Determination of forage yield and quality of pea (Pisum sativum L.) mixtures with oat and barley. Turk. J. Field Crops 17:96-99.

Kyriazopoulos, A.P., E.M. Abraham, Z.M. Parissi, Z. Koukoura and A.S. Nastis. 2012. Forage production and nutritive value of Dactylis glomerata and Trifolium subterraneum mixtures under different shading treatments. Grass Forage Sci. 68:72-82.

Marshall, H.G., M.E. McDaniel and L.M. Cregger. 1992. Cultural practices for growing oat in the United States. Agronomy Monograph, No. 33. In: H.G. Marshall and M.E. Sorrells (eds.). Oat science and technology. Crop Sci. Soc. Madison, WI. USA.

Mauro, R.P., A. Occhipinti, A.M.G. Longo and G. Mauromicale. 2011. Effects of shading on chlorophyll content, chlorophyll fluorescence and photosynthesis of subterranean clover. J. Agron. Crop Sci. 197:57-66.

Mela, T. 2003. Red clover grown in mixture with grasses: yield, persistence and dynamics of quality characteristics. Agric. Food Sci. 12:195-212.

Rinne, M. and A. Nykanen. 2000. Timing of primary growth harvest affects the yield and nutritive value of timothyred clover mixture. Agri. Food Sci. 9:121-134

Ross, S.M., J.R. King, J.T. O’Donovan and R.C. Izaurralde. 2003. Seeding rate effects on oat-berseem clover intercrops. Can. J. Plant Sci. 83:769-778.

Ross, S.M., J.R. King, J.T. O’Donovan and D. Spaner. 2004. Forage potential of intercropping berseem clover with barley, oat, or triticale. Agron. J. 96:1013-1020.

Ross, S.M., J.R. King, J.T. O’Donovan and D. Spaner. 2005a. The productivity of oats and berseem clover intercrops. I. Primary growth characteristics and forage quality at four densities of oats. Grass Forage Sci. 60:74-86.

Ross, S.M., J.R. King, J.T. O’Donovan and D. Spaner. 2005b. The productivity of oats and berseem clover intercrops. II. Effects of cutting date and density of oats on annual forage yield. Grass and Forage Sci. 60:87-98.

SAS Institute. 2001. Step-by-step programming with base SAS® Software. Cary: SAS Institute Inc. North Carolina, USA.

Shoaib, M., M. Ayub, M.S.I. Zamir and M. J. Akhtar. 2013. Dry matter yield of oat-Egyptian clover mixture under varying proportions and different growth stages of oat. Int. J. Agri. Biol. 15:673-679.

Smith, T. 2007. Oat offers options; planted in the spring or fall, forage oats lend flexibility. Angus J. 149-150.

Stout, D.G., B. Brooke, J.W. Hall and D.J. Thompson. 1997. Forage yield and quality from intercropped barley, annual ryegrass and different annual legumes. Grass and Forage Sci. 52, 298-308.

Van Soest, P.J. and J.B. Robertson. 1980. Systems analyses for evaluation of fibrous feeds. In: W.J. Pigden et al. 
(eds.), Standardization of Analytical Methodology for Feeds IDRC-134e. Ottawa; pp.49-60.

Vasilakoglou, I. and K. Dhima. 2008. Forage yield and competition indices of berseem clover intercropped with barley. Agron. J. 100:1749-1756.

Watson, V.H., H. Charles, E.K. William and A.P. Henry. 1984. Shade tolerance of grass and legume germplasm for use in the southern forest range. J. Range Manage. $37: 229-232$.
Willey, R.W. 1979. Intercropping- its importance and research needs. Part 2. Agronomy and Research Approaches. Field Crop Abstr. 32:73-85.

Younas, M. 2013. The dairy value chain: a promoter of development and employment in Pakistan. Working Paper No. 9. International Center for Development and Decent Work. Kassel, Germany,

Younas, M., and M. Yaqoob. 2005. Feed resources of livestock in the Punjab, Pakistan. Livestock Res. Rural Dev. Vol. 17, Art. \# 18. Available online at http://www.cipav.org.co/lrrd//rrd17/2/youn17018.htm. 